DOI: $10.17951 / f b .2019 .61 .99-123$

\author{
Zdzisław Gębołyś \\ Instytut Filozofii \\ Uniwersytet Kazimierza Wielkiego w Bydgoszczy \\ https://orcid.org/0000-0001-6322-478X
}

\title{
BIBLIOTEKARZE BIBLIOTEK UNIWERSYTECKICH, DWORSKICH \\ I MIEJSKICH NA ZIEMIACH NIEMIECKICH W LATACH 1789-1871 WOBEC GROMADZENIA I PRZECHOWYWANIA ZBIORÓW
}

\begin{abstract}
Streszczenie: Wiek XIX przyniósł liczne zmiany w życiu politycznym, społecznym i ekonomicznym, które odcisnęły piętno również na bibliotekach. Widać to zwłaszcza na przykładzie bibliotek od dawna działających, służących zarówno nauce, jak i tak zwanej szerokiej publiczności. Na przykładzie niemieckich bibliotek dworskich, uniwersyteckich i miejskich z lat 1789-1871 pragniemy pokazać, jak zmiany te wpłynęły na realizację podstawowych wówczas funkcji bibliotecznych, tj. gromadzenia i przechowywania zbiorów. Do typowych problemów w zakresie gromadzenia zbiorów należały: niski poziom zakupu nowości wydawniczych, nieregularny dopływ egzemplarza obowiązkowego, spory dopływ darów pochodzących z rozwiązanych bibliotek klasztornych, także uniwersyteckich, wzrost znaczenia wymiany jako formy pozyskiwania zbiorów oraz stosunkowo niski budżet na zakup. W zakresie przechowywania zbiorów działalność bibliotek niemieckich ograniczały w dużym stopniu przestarzałe gmachy o niewielkich, niewystarczających powierzchniach magazynowych. Próbowano temu zaradzić, modyfikując systemy ustawienia zbiorów, czasami remontując budynki bibliotek. Istotnym problemem były też piętrzące się stosy czasopism, które trzeba było oprawić, aby uchronić je przez zniszczeniem. Bibliotekarze stawiali czoła tym problemom, często w nierównej walce z ograniczeniami natury politycznej bądź ekonomicznej, nierzadko płynącymi z utrwalonych przyzwyczajeń.
\end{abstract}

Słowa kluczowe: biblioteki dworskie, biblioteki miejskie, biblioteki uniwersyteckie, Niemcy, gromadzenie zbiorów, przechowywanie zbiorów, bibliotekarze, 1789-1871

\section{Librarians of University, Court and Municipal Libraries in Germany in the Years 1789-1871 Towards the Collection and Storage of Collections}

Abstract: The $19^{\text {th }}$ century brought numerous changes in political, social and economic life, which also left their mark on libraries. This is especially illustrated by the example of libraries that had been operating for a long time, serving both science and the so-called wide audience. Based on the example of court, university and city libraries in Germany from 1789 to 1871, we want to 
show how these changes affected the implementation of the basic library functions at that time, i.e. acquisition and storage of collections. Typical problems in accumulating collections included: low purchase of new publications; irregular supply of the legal deposit copy; a large inflow of gifts from dissolved monastery libraries, including university libraries; the increase in the importance of exchange as a form of collecting and the relatively low purchase budget. In the field of storage of collections, the activity of German libraries was largely limited by outdated buildings with small, insufficient storage space. Attempts have been made to remedy this by modifying the collection settings systems, sometimes renovating library buildings. An important problem was also the piles of magazines that had to be bound to protect them from destruction. Librarians faced these problems, often in an uneven fight against political or economic restrictions, often deriving from established habits.

Keywords: court libraries, city libraries, university libraries, Germany, accumulating collections, storage of collections, librarians, 1789-1871

Efekty pracy bibliotekarzy najłatwiej można dostrzec w działaniach wydanych w druku, tj. dzięki katalogom, książkom i artykułom dotyczącym bibliotek. Namacalnym dowodem uznania ich działalności były też nadawane tytuły i godności, np. radcy dworu czy też odznaczenia państwowe ${ }^{1}$. Mniej trwały i mniej spektakularny charakter miały wyniki osiągane w codziennej pracy, aczkolwiek to one właśnie decydowały o odbiorze biblioteki i na ich podstawie kształtowano wizerunek bibliotekarza wśród użytkowników. Właściwą i obiektywną podstawą analizy dokonań bibliotekarzy wydają się być funkcje realizowane przez biblioteki, czyli gromadzenie, opracowanie, przechowywanie i udostępnianie zbiorów. Jest to wartość mająca zastosowanie do wszystkich bibliotek, niezależnie od różnic wynikających z typu, wielkości biblioteki i innych czynników. Większość określających ją czynników miało charakter obiektywny, np. niedostateczne środki finansowe, krótki czas pracy. Jak zawsze jednak niezmiernie dużo zależało od człowieka, a zwłaszcza od jego zaangażowania w wykonywane obowiązki. To ostatnie pomagało przezwyciężać piętrzące się trudności. Dlatego nie będzie błędem potraktowanie rezultatów pracy bibliotekarzy jako emanacji ich poglądów na zawód bibliotekarski.

Przedmiotem naszego omówienia uczyniliśmy biblioteki dworskie, uniwersyteckie i miejskie na ziemiach niemieckich w latach 1789-1871. Ani wybór bibliotek, ani też zasięg chronologiczny nie był dziełem przypadku. Nie będziemy tu wprawdzie dokonywać charakterystyki tych bibliotek z uwagi na fakt, że to poboczny wątek wobec głównego tematu. Chcielibyśmy jednak w kilku zdaniach uzasadnić ten wybór. Wybór został podyktowany co najmniej kilkoma względami. Po pierwsze determinantą był typ bibliotek, a co za tym idzie - szeroki profil gromadzonych

\footnotetext{
${ }^{1}$ Był to zwyczaj rozpowszechniony zwłaszcza w państwie pruskim.
} 
zbiorów. Biblioteki tu omawiane różniły się od siebie wielkością zasobów, stanem zatrudnienia, wysokością środków finansowych przeznaczanych na zakup książek, czasopism i zbiorów specjalnych. Wiele je jednak łączyło. Mówiąc o gromadzeniu i przechowywaniu zbiorów, mamy tu na myśli przede wszystkim ogólny profil zbiorów, różnorodność form gromadzenia, prowadzenie katalogów, stosowane systemy ustawienia zbiorów itd. Lata 1789-1871 to ważny okres w ewolucji działalności bibliotek naukowych. Przyszło im się zmagać z wieloma problemami, będącymi pokłosiem burzliwych, często bardzo dynamicznych wydarzeń politycznych. Przez ziemie niemieckie w XIX wieku przetoczyły się wojny napoleońskie, niosące nie tylko zniszczenia, ale także doprowadzające do przemieszczenia księgozbiorów. Sekularyzacja zakonów wzbogaciła z jednej strony biblioteki o nierzadko bardzo cenne księgozbiory, powiększyła znacznie ich wielkość, z drugiej strony postawiła je wobec problemu wcielenia nowych nabytków do bibliotek, w czym nie pomagał często skromny personel. Rozbicie polityczne Niemiec nie ułatwiało, a raczej utrudniało racjonalną politykę w zakresie gromadzenia zbiorów, utrudniając pracę nad tym procesem w bardzo wielu krajach. Tego problemu nie rozwiązało zjednoczenie Niemiec pod berłem Prus w 1871 roku, de facto afirmujące wcześniejszą różnorodność, podporządkowujące ją jednemu władcy, cesarzowi Niemiec ${ }^{2}$. Warto też wspomnieć o czynniku osobowym. Funkcjonowanie bibliotek, w tym realizacja jej żywotnych funkcji, zależało w dużym stopniu od kwalifikacji personelu, a te $\mathrm{w}$ wielu przypadkach pozostawiały wiele do życzenia; dotyczyło to zwłaszcza bibliotek miejskich pozostawionych na pastwę przypadkowych, nieznających rzemiosła bibliotekarskiego osób ${ }^{3}$.

\section{Gromadzenie zbiorów}

Podstawową funkcją bibliotek dziewiętnastowiecznych, zwłaszcza książnic o charakterze naukowym, pozostawało gromadzenie i przechowywanie zbiorów. Udostępnianie zbiorów, nawet w bibliotekach wręcz powołanych do obsługi określonego

2 Więcej na temat dziejów bibliotek niemieckich w XIX wieku zob.: E. Mehl, K. Hannemann, Deutsche Bibliotheksgeschichte, Berlin 1956; J. Vorstius, S. Joost, Grundzüge der Bibliotheksgeschichte, 8 Aufl, Wiesbaden 1980; K.H. Weimann, Bibliotheksgeschichte. München 1975; Handbuch der Bibliothekswissenschaft, Begründet von F. Milkau 2 verm. und verbes. Aufl. Hrsg. von G. Leyh. Bd. 1-3, Wiesbaden 1952-1961; G. Leyh, Die deutschen Bibliotheken von der Aufklärung bis zur Gegenwart, Wiesbaden 1956; L. Buzás, Deutsche Bibliotheksgeschichte der neuesten Zeit (1800-1945), Wiesbaden 1978; W. Schmitz, Deutsche Bibliotheksgeschichte, Frankfurt a. M. 2007.

3 Zob. Z. Gębołyś, Uczeni, poeci i inni - bibliotekarze miejscy na ziemiach niemieckich w latach 1789-1871, [w:] Kultura ksiązki i informacji. Księga jubileuszowa dedykowana Profesor Elżbiecie Gondek, red. A. Pulikowski, Katowice 2017, s. 211-232. 
środowiska, jak biblioteki uniwersyteckie czy szkolne, ze względu na bardzo ograniczony zasięg pełniło rolę funkcji regulacyjnej (regulowanie zachowań członków organizacji) ${ }^{4}$. Gromadzenie zbiorów pociągało za sobą największy ciężar odpowiedzialności i kłopotów. Były one poniekąd pochodną problemów poszczególnych typów bibliotek, obiektywnych i subiektywnych, wspólnych dla różnych typów bibliotek oraz specyficznych dla danego rodzaju: brak pieniędzy na zakup, przejmowanie spuścizny rozwiązywanych klasztorów, zabezpieczanie potrzeb dydaktycznych i naukowych. Pewnie dlatego zadanie to było najczęściej przypisane osobie kierującej biblioteką ${ }^{5}$.

\section{Formy gromadzenia}

Preferencje w zakresie gromadzenia są dość wyraźne i zbieżne w różnych bibliotekach, w szczególności w bibliotekach uniwersyteckich, dworskich i miejskich. Najczęściej księgozbiory uzupełniano przez pozyskiwanie „staroci”6: na aukcjach, $\mathrm{w}$ drodze darowizn, wymiany. Kluczowym zabiegiem w gromadzeniu było otrzymywanie egzemplarza obowiązkowego, przy czym chodzi tylko o te biblioteki, które miały prawo do jego posiadania ${ }^{7}$, oraz przekazywanie zbiorów przez rozwiązywane biblioteki klasztorne i uniwersyteckie ${ }^{8}$. Zakup nowości był czymś bardzo rzadkim, stąd preferowano zakupy na aukcjach, na których przeciętne ceny książek były niższe niż w handlu księgarskim9. Spośród bibliotekarzy uniwersyteckich wyróżniał się pod tym względem Friedrich Gottlieb Welcker z Bonn, który preferował zakupy właśnie

${ }^{4}$ Funkcją regulacyjną było też opracowanie rzeczowe zbiorów.

5 W bibliotekach uniwersyteckich oraz niektórych bibliotekach miejskich i dworskich za gromadzenie zbiorów odpowiedzialne były ciała doradcze w rodzaju komisji bibliotecznej lub zajmował się tym wyższy urzędnik dworski. Zob. Verordnung für die Bibliothek der Grossherzoglichen Ludewigs-Universität zu Giessen, „Inteligenz-Blatt zum Serapeum” 1844, Nr. 11, s. 161-164.

${ }^{6}$ Jest tu mowa nie o dziełach zużytych, lecz znajdujących się już wcześniej w czyimś posiadaniu.

7 Z przeglądu statystycznego BU Heidelberg w 1. 1838-1871 dokonanego przez H. Vogelera wynika, iż egzemplarz obowiązkowy stanowił w ciągu roku średnio ok. $20 \%$ wszystkich wpływów. Zob. H. Vogeler, Johann Christian Felix Bähr als Oberbibliothekar der Universitätsbibliothek Heidelberg (1832-1872), „Bibliothek und Wissenschaft” 1970, Bd. 5, s. 90-92.

${ }^{8} \mathrm{~W}$ pierwszym przypadku można podać jako przykład BU Erlangen, do której włączono w 1818 r. bibliotekę rozwiązanego uniwersytetu w Altdorf. Zob. J.C. Irmischer, Diplomatische Beschreibung der Manuscripte welche sich in der Königl. Universitätsbibliothek Erlangen befinden, Erlangen 1829, s. 133-142; Znacznie wzbogaciła się dzięki księgozbiorom poklasztornym BU Landshut. Zob. L. Buzás, Geschichte der Universitätsbibliothek München, Wiesbaden 1972, s. 112 114; BU Wrocław powstała w istocie na bazie rozwiązanej BU Frankfurt n/O (28 000 t.), skupiającej księgozbiory śląskich klasztorów i konwiktów. Zob. Lexikon des gesamten Buchwesens, Hrsg. von K. Löffler und J. Kirchner, Leipzig 1935, Bd. 1, s. 258.

9 Zob. P.M. Ehrle, Bibliothekspolitik im Vormärz. Robert von Mohl und die Universitätsbibliothek Tübingen, [w:] Bibliotheken im gesellschaftlichen und kulturellen Wandel des 19. Jahrhundert, Hrsg. P. Vodosek, Hamburg 1982, s. 25. 
na aukcji ${ }^{10}$. Równomiernie starał się traktować wszystkie formy zakupu, w tym zakup nowości, Johann Christian Felix Bähr (BU ${ }^{11}$ Heidelberg). Niestety często uniemożliwiał mu to brak funduszy ${ }^{12}$. Christian Gottlob Heyne (BU Getynga) kontynuował wprawdzie zapoczątkowane przez Ernsta Schlütera zakupy antykwaryczne, ale był zarazem w dziejach getyńskiej książnicy pionierem planowego zakupu nowości ${ }^{13}$.

Sprawnymi i biegłymi nabywcami książek na aukcjach byli m.in. Gottfried Bernhardy (BU Halle), Paul Jakob Bruns (BU Wittenberga), Karl Gotthelf Gersdorf (BU Lipsk), Friedrich Wilken (BD ${ }^{14}$ Berlin), Helfrich Bernhard Wenck (BD Darmstadt), Ludwig Wilhelm Christian von Halem (BD Oldenburg). Bruns próbował podnieść bibliotekę pozostawioną w upadku przez swego poprzednika, Franza Dominikusa Häberlina, zakupami książek na aukcjach. Otrzymywał na nie od księcia częstokroć sumy przekraczające roczny budżet biblioteki, np. w 1789 r. - 500 talarów ${ }^{15}$. W rezultacie doprowadził do znacznego wzrostu liczby użytkowników. Starania o zakup nowości Bruns podejmował, jeszcze będąc drugim bibliotekarzem. W 1783 r. wystąpił nawet w tej sprawie z listem do ministra stanu Karla Augusta von Hardenberga, w którym odmalował opłakany stan biblioteki i przestrzegał, że jeśli „,biblioteka nie otrzyma nadzwyczajnych środków, należy się obawiać, iż [...] pozostanie daleko w tyle za siostrzanymi akademiami” ${ }^{16}$. O kilka dużych księgozbiorów prywatnych wzbogacił lipską bibliotekę uniwersytecką K.E. Gersdorf. Swoje credo na temat zasad gromadzenia zawarł w zbiorze propozycji dotyczących sanacji biblioteki [Unmassgebliche Vorschläge, eine zweckmässige Einrichtung der Leipziger Universitäts, Bibliothek bettreffend $]^{17}$. Postulował tam m.in. uzupełnienie luk w księgozbiorze, dokonywanie zakupu według stałych zasad bez preferowania jakiegokolwiek działu oraz podniesienie funduszu na zakup książek ${ }^{18}$. Bezpośrednim następcą Gersdorfa, a zarazem

10 W. Erman, Geschichte der Bonner Universitätsbibliothek (1818-1901), Halle 1919, s. 106-115.

11 Biblioteka uniwersytecka.

12 H. Vogeler, op. cit., s. 85-95.

13 B. Fabian, Die Göttinger Universitätsbibliothek im achtzehnten Jahrundert, „Göttinger Jahrbuch” 1980, s. 118-119. Biblioteka getyńska uczestniczyła przeciętnie w ponad 10 aukcjach w roku. Zob. A. Hessel, Heyne als Bibliothekar, „Zentralblatt für Bibliothekswesen” 1928, H. 9-10, s. 467.

14 Biblioteka dworska.

15 M. Köhler, Ueber öffentliche Anstalten zur Verbesserung der Academischen Sitten, „Guttenberg Jahrbuch" 1989, s. 347. Były to przeważnie księgozbiory prywatne.

${ }^{16}$ Ibidem. Apel ten odniósł pewien skutek. Dzięki kupowaniu przez 15 lat książek na aukcjach Bruns uzupełnił wszystkie większe luki w księgozbiorze.

17 Memoriał ten napisał Gersdorf w 1833 r., tj. w chwili obejmowania urzędu bibliotekarza uniwersyteckiego. Zob. G. Loh, Ernst Gersdorfs Tätigkeit als Oberbibliothekar an der Universitätsbibliothek Leipzig (1833-1874), [w:] Studien zum Buch und Bibliothekswesen, Bd. 5, Leipzig 1987, s. 58-59.

18 Ibidem. Trzeba przyznać, że udało mu się dopiąć postawionych celów. Na przykład księgozbiór wzrósł blisko sześciokrotnie. 
kontynuatorem jego idei był Christoph Ludolf Ehrenfried Krehl. Nabył on dla biblioteki księgozbiory Johanna Wolfganga Goethego, Karla Friedricha Salomona Hirzela. Nade wszystko troszczył się jednak o swoją własną dziedzinę, tj. filologię orientalną ${ }^{19}$. Zakup aukcyjny preferował też w Oldenburgu L. W. Ch. v. Halem. Od 1805 r. przeznaczał na ten cel 1/3 całego rocznego budżetu. Kupował również prywatne księgozbiory, a z nowości głównie kontynuacje. Za jego kadencji nastąpił blisko trzykrotny przyrost księgozbioru z 21000 t. (1792) na 60000 t. $(1840)^{20}$.

\section{Dary}

Dary, zwłaszcza pochodzące od profesorów, urzędników i arystokratów, stanowiły właściwie przez cały XIX wiek bezcenne źródło powiększenia księgozbioru. Ich przeznaczenie potęgowały ustawiczne kłopoty finansowe bibliotek uniwersyteckich. Nic zatem dziwnego, że w Bonn za kadencji Jakoba Bernaysa (1865-1881) doszło nawet do zwiększenia darów oraz odczuwalnego wzmocnienia zakupów przez fundacje. Był to kąsek nie do pogardzenia dla Bernaysa, zwłaszcza że zmniejszeniu uległy wpływy z tytułu egzemplarza obowiązkowego ${ }^{21}$. Do grona tych, którzy nieustannie zabiegali o nowe dary i względy darczyńców, należeli też bibliotekarze bibliotek dworskich i miejskich: Heinrich Joachim Jaeck (BD Bamberg), Friedrich Adolf Ebert (BD Drezno), Johann Gottfried Geissler (BD Gotha), Josef Gerhard Laurent (BM Akwizgran), Johann Jacob Lucius (BM ${ }^{22}$ Frankfurt n. M.). Wśród darów przeważały małe kolekcje liczące kilkaset tomów. Zdarzało się też pozyskiwanie mniej liczebnych księgozbiorów. W 1830 r. F.A. Ebert pozyskał w darze dla biblioteki od tajnego radcy finansowego von Wagnera zbiór rozpraw prawniczych liczący 11539 sztuk $^{23}$. Znacznie częściej wzbogacenie tego rodzaju następowało w drodze regulacji nadzwyczajnych. Na przełomie XVIII i XIX wieku były to przede wszystkim: sekularyzacja zakonów, rozwiązanie wielu uniwersytetów. Skwapliwie skorzystał z okazji rozwiązania uniwersytetu w Altdorf dyrektor BU w Erlangen Gottlieb Ernst August Mehmel ${ }^{24}$. Gdy tylko zapadła decyzja o przekazaniu księgozbioru do Erlangen (1818 r.), udał się tam,

19 E. Zarncke, Ludolf Krehl, „Zentralblatt für Bibliothekswesen” 1901, H. 12, s. 616-618.

${ }^{20}$ Ważne źródło powiększania biblioteki stanowiły też dary od księcia i od urzędników z Oldenburga i Eutin oraz odkupienie za połowę ceny książek od Towarzystwa Czytelniczego na mocy umowy z 1804 r. Zob. G. Crusius, Gründung und Frühgeschichte der Herzoglichen öffentlichen Bibliothek in Oldenburg (1792-1847), Oldenburg 1981, s. 25-27.

${ }^{21}$ W. Erman, op. cit., s. 219-225.

${ }^{22}$ Biblioteka Miejska.

${ }_{23}$ F. Nestler, Friedrich AdolfEbert und seine Stellung im nationalen Erbe der Bibliothekswissenschaft, Leipzig 1969, s. 112.

24 Uniwersytet został rozwiązany przez króla Maksymiliana Józefa w 1809 r. Zob. J.C. Irmischer, op. cit., s. 133. 
by go osobiście odebrać25. Koniunkturę polityczną wykorzystał również bibliotekarz uniwersytecki z Marburga - Johannes Bering. Sprowadził on do biblioteki ok. 4000 tomów z rozwiązanych uniwersytetów w Rinteln i Helmstedt oraz prawie 7000 tomów z bibliotek klasztornych w Lucklum i Corvey, dzięki wsparciu króla Westfalii Hieronima ${ }^{26}$. Jeszcze większego wyczynu dokonał Hans Joachim Jaeck. Doprowadził on do połączenia 11 bibliotek klasztornych, konwiktowych i starej biblioteki uniwersyteckiej. Jaeck, podobnie jak F. Wilken i Paul Hupfauer, wchodził w skład komisji likwidacyjnej, przejmującej zbiory rozwiązanych klasztorów ${ }^{27}$.

Bilans zasług bibliotekarzy niemieckich, wynikających z uwarunkowań politycznych, trzeba bezwzględnie poszerzyć o ratowanie zagrożonych działaniami wojennymi księgozbiorów (Gottlieb Wilhelm Gerlach) ${ }^{28}$ oraz o udział w rewindykowaniu księgozbiorów zagrabionych przez wojska napoleońskie (Jacob Grimm) ${ }^{29}$.

\section{Egzemplarz obowiazkowy}

Dzieje dziewiętnastowiecznych niemieckich bibliotek naukowych zapisane są zmaganiami bibliotekarzy $\mathrm{z}$ wydawcami i księgarzami o regularne dostarczanie egzemplarza obowiązkowego (e.o.). Stroną bibliotekarską w tych sporach byli zazwyczaj bibliotekarze uniwersyteccy i dworscy. Im najbardziej zależało na tym, by do bibliotek napływała wydawana na bieżąco literatura krajowa, zwłaszcza że władze zwierzchnie nie zawsze zaspokajały potrzeby finansowe placówek bibliotecznych. Spośród bibliotekarzy uniwersyteckich o systematyczną dostawę egzemplarza obowiązkowego troszczyli się m.in. bibliotekarze z Bonn: F. G. Welcker i Friedrich Wilhelm Ritschl; z Giessen: Christian Gottlieb Kühnol i Johann Ernst Christian Schmidt; z Marburga: Johann Melchior Hartmann i Karl Friedrich Hermann. O regularny napływ e.o. dbali też bibliotekarze dworscy: J. Grimm, Georg Heinrich Ludwig Nicolovius, Johann Erich Biester, Friedrich Ludwig Wagner oraz bibliotekarze z bibliotek miejskich, m.in. Christoph Daniel Ebeling.

Nad ścisłym respektowaniem przepisów o egzemplarzu obowiązkowym czuwał szczególnie F.G. Welcker. Stosowne rozporządzenie rozciągnął na dzieła drukowa-

${ }^{25}$ Ibidem, s. 133-142. Transport książek został zakończony w ciągu kilku dni. Być może Mehmel obawiał się, że może nie dojść do jego realizacji, tak jak to miało miejsce z biblioteką kościelną w Schwabach.

${ }_{26}$ G. Zedler, Geschichte der Universitätsbibliothek zu Marburg 1527-1887, Marburg 1896, s. 11.

${ }_{27}$ Zob. H.J. Jaeck, Völlstandige Beschreibung der öffentlichen Bibliothek zu Bamberg, Nürnberg 1831, s. CCI.

${ }^{28}$ Die Rettung der Wittenberger Universitätsbibliothek im Jahre 1813 durch ihren ersten Custos G.W. Gerlach, „Inteligenz-Blatt zum Serapeum” 1862, Nr. 14, s. 105-109. Chodzi o uratowanie biblioteki uniwersyteckiej przed wojskami napoleońskimi.

${ }^{29}$ Landesbibliothek Kassel 1580-1930, Hrsg. von W. Hopf, Marburg 1930, t. 1, s. 69. 
ne i wydawane za granicą przez rodzimych edytorów. Niesumiennych wydawców zgłaszał do kuratorium uniwersyteckiego. Nie wahał się zarazem niszczyć lub sprzedawać książek niepotrzebnych bibliotece, otrzymanych tą drogą, przeznaczając zdobyte pieniądze na zakup ${ }^{30}$. August Friedrich Pfeiffer (BU Erlangen) swą skargę na opieszałe dostarczanie e.o. przez drukarnię gazet w Bayreuth skierował w $1797 \mathrm{r}$. do ministra stanu Karla Augusta von Hardenberga ${ }^{31}$. Jeszcze ostrzej zareagował na opieszałość wydawców nadbibliotekarz BU Heidelberg, J. Ch. F. Bähr, wytaczając im sprawy sądowe ${ }^{32}$. Bodaj najskuteczniejszy i najbardziej spektakularny charakter miała rozprawa J. Grimma z niesumiennymi wydawcami ${ }^{33}$. Wyposażony w pełnomocnictwa, zażądał 15 grudnia 1817 r. od rządów w Kassel, Marburgu i Hanau wyrównania zaległości od 1 listopada 1813 r. w dostarczeniu e.o. Konieczność przedsięwzięcia uzasadniał następującymi słowami: „Zasadność tego rozporządzenia polega w mniejszym stopniu na tym, by stworzyć bibliotece nic nie kosztujący przyrost ważnych książek, lecz by móc zachować dla potomności na tej drodze pewne druki ojczyste, które mają w sobie błahą treść, ale dla historii heskiej mogą otrzymać przypadkowo wartość, podczas gdy w rękach zwykłych prywatnych ludzi łatwo i często już po kilku latach mogą zostać rozproszone. Tutaj należą nawet prowizoryczne tygodniowe ogłoszenia i dzienniki ogłoszeń" ${ }^{34}$. Sukces pisma był pełny. Od tego momentu e.o. zaczął napływać do biblioteki bardzo regularnie ${ }^{35}$. Pomyślnie zakończyły się też boje Ch.D. Ebelinga o respektowanie zarządzenia o e.o. Na jego wniosek Rada Miejska Hamburga zobowiązała w 1800 r. tamtejszych drukarzy do przekazywania bibliotece miejskiej dwóch egzemplarzy każdego dzieła ${ }^{36}$.

Bibliotekarze starali się nie tylko egzekwować dostarczanie e.o., ale również wpływać na taką treść rozporządzeń w tej kwestii, by zapewnić przepisom skuteczność i wykonalność. Autorem bardzo skutecznego rozporządzenia o e.o. z 1805 i 1808 r. dla Hesji był Friedrich Ludwig Wagner, bibliotekarz dworski w Darmstadt $(1803-1811)^{37}$. W procesie walki o konsekwentne przestrzeganie postanowień

${ }^{30}$ W. Erman, op. cit., s. 117-119. Welcker traktował egzemplarz obowiązkowy, podobnie jak generacja starszych bibliotekarzy uniwersyteckich, jako środek do łatwego wzbogacenia biblioteki.

${ }^{31}$ Reakcja ministra była po myśli Pfeiffera. Nakazał on księgarzom księstwa Bayreuth przesyłanie egzemplarza obowiązkowego do BU Erlangen. Zob. H.-D. Keunecke, Die Universitätsbibliothek Erlangen als Pflichtbibliothek vor 1840, „Bibliotheksforum Bayern” 1986, H. 2, s. 166-167.

32 H. Vogeler, op. cit., s. 87.

${ }^{33}$ Chodzi o jego okres pracy w BD Kassel.

${ }^{34}$ Die Landesbibliothek Kessel..., s. 74.

35 Przypuszczalnie dzięki niemu biblioteka nie posiada luk w zbiorach z tego okresu.

36 Zob. Ch. Petersen, Geschichte der Hamburgischen Stadtbibliothek, Hamburg 1838, s. 107-108.

37 Zob. H. Berndt, Vom Berufsbild der Darmstädter Bibliothekare, [w:] Durch der Jahrhunderte Strom. Beiträge zur Geschichte der Hessischen Landes-und Hochschulbibliothek Darmstadt, Hrsg. E. Zimmermann, Frankfurt a. M. 1967, s. 39. 
rozporządzenia o e.o. z 1803 r. dla średniej Frankonii A.F. Pfeiffer z BU Erlangen przygotował projekt aktu wykonawczego, który wszedł w życie 15 marca tego samego roku ${ }^{38}$.

\section{Wymiana}

Wymianę druków i rękopisów mogły prowadzić ze sobą wszystkie biblioteki, choć nie przybrało to wielkiego zasięgu. Najwcześniej na ziemiach niemieckich nadano jej normy prawne w Prusach. Kolejne rozporządzenia ministerialne z 26 maja 1819 r., 26 października 1820 r. i 17 marca 1821 r. ustanawiały wymianę między pruskimi bibliotekami uniwersyteckimi po 2 egzemplarze każdego wydanego dzieła ${ }^{39}$. Wymiana była również ważnym źródłem gromadzenia w niepruskich bibliotekach uniwersyteckich. W badeńskim Heidelbergu już w 1820 r. podpisano umowę na ten temat z BU Bonn. Rozwój wymiany w Heidelbergu nastąpił w czasie urzędowania nadbibliotekarza Johanna Christiana Felixa Bähra. W latach 1838-1871 liczba wydawnictw własnych uczelni stanowiła około 50\% wszystkich rocznych nabytków biblioteki ${ }^{40}$. Chronologicznie rzecz biorąc, inicjatorem akademickiej wymiany druków był heski Marburg. Za kadencji Johannesa Hartmanna został utworzony w 1817 r. akademicki Związek Wymiany (Akademischer Tauschverein), którego zasadniczym celem była wymiana druków między uniwersytetami Związku Niemieckiego i innymi niemieckimi uczelniami ${ }^{41}$. Stosunkowo najbardziej rozwiniętą wymianę druków prowadziła BU w Bonn. Duża w tym zasługa jej szefa, F.G. Welckera, który, nim przyłączył się do Związku Marburskiego (1838 r.), nawiązał kontakty z większością uniwersytetów niemieckich i niektórymi zagranicznymi ${ }^{42}$. Na wniosek Welckera dołączono też do wcześniej wspomnianych rozporządzeń programy i publikacje periodyczne. Wymiana w bibliotekach dworskich dotyczyła przeważnie starodruków i rękopisów. Jej propagatorem był np. F.A. Ebert. Usiłował on uzyskać drogą wymiany od tajnego archiwum państwowego wartościowe rękopisy historyczne ${ }^{43}$.

${ }^{38}$ Zarządzenie zobowiązywało poszczególnych drukarzy i wydawców do dostawy bibliotece uniwersyteckiej egzemplarza obowiązkowego oraz katalogów targowych i wydawniczych. Zob. H.-O. Keunecke, op. cit., s. 168-169.

39 W. Erman, op. cit., s. 119-125.

${ }^{40}$ H. Vogeler, op. cit., s. 90-92. Należy zauważyć, że przedmiotem wymiany były tam dysertacje.

${ }^{41}$ G. Zedler, op. cit., s. 11. W skład związku wchodziło m.in. Wilno od 1838 r.

42 W 1824 r. Welcker rozpoczął wymianę druków z Krakowem. Zob. W. Erman, op. cit., s. 119-125.

${ }^{43}$ F. Nestler, op. cit., s. 112. 
Efektem zabiegów i starań bibliotekarzy, czy to o egzemplarz obowiązkowy, czy też o druki z wymiany bądź o darowizny, był mniejszy lub większy - w każdym razie stopniowy - przyrost księgozbioru. Miałby on jednak charakter tylko podstawowy, gdyby nie zakup, będący bezsprzecznie głównym źródłem gromadzenia, spowodowany wzrostem nakładów finansowych na ten cel. Dlatego też, mówiąc o powiększeniu zbiorów biblioteki, nie można tracić z pola widzenia tego ostatniego aspektu. Działania bibliotekarzy uniwersyteckich w tym względzie dają się przyrównać do ciągłego, aczkolwiek powolnego drążenia skały przez wodę. F.G. Welckerowi udało się powiększyć budżet biblioteki z 4000 talarów w 1818 r. do 6100 talarów w 1843 r. Na zakup książek i ich oprawę przeznaczano przeciętnie w roku $2 / 3$ tej sumy ${ }^{44}$. F.W. Ritschl przyczynił się do wzrostu budżetu do wysokości 6605 talarów, jednak dopiero J. Bernays, jego następca, osiągnął w 1872 r. poziom ponad 10000 talarów $(10250)^{45}$. Powiększenie budżetu dla getyńskiej biblioteki uniwersyteckiej mogło dojść do skutku dzięki współdziałaniu urzędujących bibliotekarzy: Karla Friedricha Christiana Höcka i L. Schweigera oraz komisji bibliotecznej. Z obu stron płynęły do kuratorium uniwersyteckiego i rządu stosowne memoriały ${ }^{46}$. W raporcie dotyczącym polityki gromadzenia z 28 sierpnia $1848 \mathrm{r}$. Schweiger ubolewał nad niedofinansowaniem biblioteki: „Tak więc nasz wspaniały zakład traci stale na swoim znaczeniu, ponieważ środki nie stoją w żadnym stosunku do tego, co musiałoby być zakupione" ${ }^{\prime \prime 7}$. Przestrzegał zarazem, że „w tym stanie rzeczy biblioteka w końcu straci na znaczeniu, jeśli łaska kuratorium uniwersyteckiego nie zagwarantuje znaczącej i stałej pomocy"48. Kuratorium nie zdobyło się na rozwiązanie korzystne dla biblioteki, tolerowało natomiast stały deficyt, przekraczający blisko $20 \%$ całego budżetu ${ }^{49}$. To, co nie udało się ani komisji, ani Ludwigowi Schweigerowi i K.F.Ch. Höckowi, powiodło się sekretarzowi bibliotecznemu Adolfowi Elissenowi, który jako poseł podniósł tę sprawę w maju $1850 \mathrm{r}$. na forum parlamentu, występując $\mathrm{z}$ wnioskiem o podwyższenie budżetu o 3000 talarów, który, mimo oporów pierwszej izby, został przyjęty. Bibliotece przyznano

${ }^{44}$ W. Erman, op. cit., s. 99-105.

${ }^{45} \mathrm{Z}$ sumy tej na zakup wydzielono 5600 talarów, a na pensje bibliotekarzy 2700 talarów. Zob. W. Erman, op. cit., s. 216-218.

467 listopada 1845 r. taki memoriał wystosowała komisja biblioteczna, w tym samym roku Höck i Schweiger. Zob. Geschichte der Göttinger Universitätsbibliothek, Hrsg. von K. J. Hartmann, H. Fuchsel, Göttingen 1937, s. 225 i nast.

${ }^{47}$ Geschichte der Göttinger Universitätsbibliothek..., s. 227.

48 Ibidem.

49 Ibidem, s. 227. W roku akademickim 1849/50 uchwalony budżet biblioteki wyniósł 5200 talarów, natomiast rzeczywiste wydatki 6150 talarów. 
roczny budżet w wysokości 8200 talarów ${ }^{50}$. O dodatkowe dotacje dla heidelberskiej biblioteki uniwersyteckiej upominał się, i to z powodzeniem, F. Wilken. Wywalczył on przeznaczenie nadwyżek z opłat studentów za światło na potrzeby biblioteki uniwersyteckiej. Uzyskał też finansowanie wydatków biblioteki z opłat za promocje, habilitacje i od nowo zatrudnionych profesorów. Po okresie stagnacji, związanej z kierowaniem biblioteką przez Franza Josepha Moné i Josepha Eiseleina, objęcie urzędu nadbibliotekarza przez J.Ch.F. Bähra i czasy sprawowania przez niego tej funckji były pomyślnym okresem dla biblioteki. Bähr przyczynił się do stopniowego wzrostu budżetu biblioteki z 1500 guldenów (1833 r.) do 4525 guldenów (1872 r.) oraz dwukrotnego powiększenia księgozbioru z 110000 (1833 r.) - do 210000 tomów (1872 r. $)^{51}$.

Katalog zasług Karla Wilhelma Göttlinga dla jenajskiej biblioteki uniwersyteckiej obejmuje również starania o podwyższenie budżetu biblioteki. Świadectwem tego są raporty z 1835 i 1839 r. W pierwszym z nich uzasadnił konieczność podwyżki w dwojaki sposób. Po pierwsze twierdził, iż „nie można oczekiwać, ani wymagać, że każdy profesor zakupi ze swojego uposażenia książki, które potrzebuje, by utrzymać kontakt z nauką" ${ }^{2} \mathrm{z}$ uwagi na jego niskie pensje. Po drugie uważał, że jeżeli Jena chce w przyszłości utrzymać swoją pozycję pośród niemieckich uniwersytetów, to „powinna także pozyskać znakomite persony [...] i tak musi fundusz uniwersytetu w ogólności dla publicznych zakładów, a zwłaszcza dla biblioteki przez stałe przychody znacznie wzrosnąc" 53 . W 1839 r. dodatkowo ostrzegał, że „z każdym dniem brak jest coraz bardziej odczuwalny, z każdym dniem luka powiększa się i jest już prawie nie do wypełnienia, z każdym dniem odczuwamy coraz boleśniej, że podczas gdy inne gałęzie uniwersytetu cieszą się łaskawością, tylko biblioteka nie jest arsenałem naukowych dążeń" ${ }^{54}$. Wysiłki Göttlinga nie były całkiem bezowocne. W 1849 r. podwyższono wydatki na zakup do 410 talarów, a w 10 lat później do 700 talarów $w^{55}$.

Za symptomatyczne należy uznać, że podobne poglądy mniej więcej w tym samym czasie wyraził tybiński nadbibliotekarz Robert von Mohl. Konkluzja jego

${ }^{50}$ Kuratorium zażądało jednak przeznaczenia nowego dodatku na zakup książek, zakazując jednocześnie zakupu periodyków. Kłopoty z funduszem na zakup książek nie ustały. Dopiero w 1875 r. nastąpiła jego znaczniejsza podwyżka o 3000 talarów. Zob. Geschichte der Göttinger Universitätsbibliothek..., s. 229 i nast.

${ }^{51}$ J.Ch. Bähr, zasiadając w latach 1830-1832 w komisji bibliotecznej, wielokrotnie występował o to, by zdobyć środki i drogę na tani zakup pożądanych dzieł. Zob. H. Vogeler, op. cit., s. 50-51.

${ }_{52}$ Geschichte der Universitätsbibliothek Jena 1549-1945, [bearb. von einer Arbeitsgemeinschaft wissenschaftlicher Bibliothekare der Universitaetsbibliothek Jena: Karl Bulling... et al.], Weimar 1958, s. $456-457$.

${ }^{53}$ Ibidem.

54 Ibidem, s. 458.

55 Ibidem. 
wręcz detalicznej analizy luk w księgozbiorze była jednoznaczna: „Ubóstwo i niedostatek [biblioteki] wypływa zresztą z jej o wiele za małej dotacji. Tylko 250 florenów przyznało państwo na książki, około ponad 1000 florenów ma biblioteka z ubocznych przychodów”56. W tej sytuacji pytał zgoła retorycznie: „Jak jest możliwe utrzymać bibliotekę uniwersytecką z 3600 florenami (wielkość całego budżetu biblioteki [ZG]) nie tylko na bieżąco, lecz jeszcze znaczne luki pokrywać?"57. Przez osiem lat kierowania biblioteką (1836-1844) Mohl ustawicznie wnioskował o dotacje. Pierwsze cztery lata mógł zaliczyć do nawet wyjątkowo udanych. Nadzwyczajne wydatki ${ }^{58}$ wynosiły rocznie 12-15 000 florenów, przekraczając maksymalnie cztery razy wysokość stałych nakładów ${ }^{59}$. Następne lata nie były tak pomyślne dla biblioteki. Trwałym osiągnięciem Mohla okazało się jednak potrojenie budżetu biblioteki do wysokości 11000 guldenów ${ }^{60}$. Osiągnięcia innych bibliotekarzy uniwersyteckich na tym polu nie są, być może, aż tak imponujące. W sytuacji jednak chronicznego braku pieniędzy nawet podwyższenie budżetu o 500 guldenów, wywalczone przez Gottfrieda Heinricha Schäfera (BU Giessen) czy jednorazowa dotacja 100 talarów zdobyta przez J. Beringa (BU Marburg) nie były dla bibliotek do pogardzenia. Zresztą powiększenie zbiorów biblioteki niekoniecznie musiało następować w drodze wzrostu funduszów. Przykładem niech będzie Olaf Gerhard Tychsen (BU Bützow), który powiększył zasób biblioteczny o 14000 tomów i 200 rękopisów, mimo bardzo ograniczonych środków, prawdopodobnie dzięki darowiznom ${ }^{61}$.

Podobne, a nawet zgoła takie same problemy napotykali na swojej bibliotekarskiej drodze bibliotekarze dworscy i miejscy. Ich stałą troską, niezależnie od wielkości biblioteki, było uzyskanie odpowiednich środków finansowych, nie tylko pozwalających na utrzymanie księgozbioru w należytym stanie, ale także na jego powiększenie. Skutecznie o podwyższenie budżetu lub funduszów na nowe nabytki walczyli m.in. tacy bibliotekarze dworscy, jak: J.E. Biester (Berlin), Helfrich Bernhard Wenck (Darmstadt), Johann Christoph Adelung (Drezno), Karl Philipp Christian Schönemann (Wolfenbüttel), Ludwig Konrad Bethmann (Wolfenbüttel). Można mówić w przypadku tego grona o dużych i małych sukcesach. W tych pierwszych kategoriach można oceniaćJ.E. Biestera, który w 1786 r. doprowadził do podniesienia budżetu z 2000 na 3000 talarów.

${ }^{56}$ K. Geiger, Robert Mohl als Vorstand der Tübinger Universitätsbibliothek (1836-1844), „Zentralblatt für Bibliothekswesen” 1900, H. 4, s. 170.

57 Ibidem. Opinię tę wypowiedział Mohl w raporcie o stanie biblioteki do rządu i parlamentu w 1833 r., tj. jeszcze przed objęciem urzędu nadbibliotekarza (1836 r.).

${ }^{58}$ Chodzi o nadwyżki z kasy uniwersyteckiej.

59 K. Geiger, Robert von Mohl..., s. 178.

${ }^{60}$ P.M. Ehrle, op. cit., s. 21. Mohl uważał, że duża biblioteka bez funduszu na zakup książek w wysokości 15-20 000 florenów rocznie nie jest w stanie spełniać swoich zadań.

${ }^{61}$ K. Bader, Lexikon deutscher Bibliothekare in Haupt-und Nebenamt bei Fürsten, Staaten und Städten, Leipzig 1925, s. 265. 
Na następną podwyżkę - do wysokości 8500 talarów - musiał jednak czekać aż 24 lata $\left(1810 \mathrm{r}\right.$. ${ }^{62}$. Pewne analogie do berlińskich osiągnięć można zaobserwować w Dreźnie. Memoriał J.Ch. Adelunga do władz zwierzchnich z 28 grudnia 1787 r. zaowocował przyznaniem przez króla bibliotece 3000 talarów rocznie ${ }^{63}$. Stan ten utrzymał się na prawie niezmienionym poziomie aż do 1865 r., czyli do objęcia urzędu nadbibliotekarza przez Ernsta Förstemanna. Przyczyną tego była zarówno niekorzystna dla Saksonii koniunktura polityczna, jak też nieudolne rządy w bibliotece Gustava Klemma ${ }^{64}$. Do małych sukcesów należą z całą pewnością starania o pieniądze Karla Philippa Christiana Schönemanna (Wolfenbüttel). Budżet Biblioteki Książęcej wynoszący 200 talarów udało mu się przy wsparciu profesora Assmanna w 1834 roku podwoićc5. W podobnych kategoriach należy traktować osiągnięcie bibliotekarza dworskiego w Kassel - Friedricha Wilhelma Striedera. W bardzo szybkim tempie wydobył on tamtejszą bibliotekę dworską ze stanu upadku, w jakim pozostawił ją jego poprzednik Jean Pierre Louis Luchet. Namacalnym tego znakiem był wzrost księgozbioru w ciągu półtora roku o $1 / 3^{66}$.

Zasługi bibliotekarzy miejskich na omawianym polu są stosunkowo najmniej znane. Żadną też miarą nie da się ich porównać z dokonaniami bibliotekarzy uniwersyteckich czy dworskich. Świetlanym wyjątkiem jest postać bibliotekarza lipskiego Emila Roberta Wilhelma Naumanna, który w okresie swojego urzędowania (1835-1880) powiększył księgozbiór trzykrotnie ${ }^{67}$. Pochlebnie zapisał się w dziejach budziszyńskiej biblioteki Johann Emanuel Käuffer, chociaż jego sukcesy mają raczej symboliczny charakter. W $1822 \mathrm{r}$. doprowadził on do odnowienia dekretu

${ }^{62}$ Zob. F. Wilken, Geschichte der Königlichen Bibliothek zu Berlin, Berlin 1828, s. 130-133. Faktem jest, że Biester przekraczał rokrocznie budżet o około 700 talarów. Następna podwyżka do 4050 talarów nastąpiła dopiero na początku kadencji Wilkena. Zob. Deutsche Staatsbibliothek 16611961, red. H. Kunze, Leipzig 1961, s. 102.

${ }_{63}$ Adelung, wnioskując o pieniądze, motywował to koniecznością uzupełnienia luk w księgozbiorze oraz wydatkami na bieżący zakup nowych dzieł. Zob. F.A. Ebert, Geschichte und Beschreibung der Königlichen öffentlichen Bibliothek zu Dresden, Leipzig 1822, s. 104 i nast.

${ }^{64} \mathrm{~W}$ wyniku kongresu wiedeńskiego terytorium Saksonii zmniejszyło się prawie o połowę. Zob. M. Mühlner, Begeisterung war die Signatur meiner Tätigkeit: die Reform der Königlichen Öffentlichen Bibliothek in Dresden unter Ernst Wilhelm Förstemann, [w:] Studien zum Buch-und Bibliothekswesen, Bd. 5 Leipzig 1987, s. 80-88. Nie był w stanie zapobiec redukcji budżetu nawet F.A. Ebert. W jego spuściźnie pozostał memoriał z $1830 \mathrm{r}$. do władz, w którym domagał się podwyższenia budżetu nie zdecydował się jednak na przesłanie memoriału, wiedząc, że wniosek nie ma szans, a ponadto obawiając się, że nie spodoba się jego ton. Zob. F. Nestler, op. cit., s. 113.

${ }^{65}$ Już do końca sprawowania urzędu (1855) nie uzyskał od władz nowych subwencji. Zob. L. Schweiger, Zur Erinnerung on Dr. Carl Philipp Christian Schönemann, Herzogl. Bibliothekar in Wolfenbüttel, und dessen Sohn, Dr Anton Wilhelm Otto Schönemann, „Serapeum” 1856, nr 8, s. 118-119.

${ }_{66}$ Die Landesbibliothek Kassel..., s. 56. Biblioteka liczyła w 1791 r. 38870 tomów.

67 H.-Ch. Mannschatz, Zur Erinnerung an Robert Naumann (1809-1880), „Bibliothekar” 1990, H. 3, s. 157-160. Ze stanu 38000 tomów (1830 r.) na 100000 tomów (1880 r.). 
radcy miejskiego, na mocy którego nowo wstępujący do rady miejskiej oraz każdy urzędnik miejski, duchowny i nauczyciel o dochodzie rocznym powyżej 300 talarów byli zobowiązani do podarowania bibliotece 3 talarów w książkach lub w naturze ${ }^{68}$.

\section{Wytyczne gromadzenia}

Zasady, według których gromadzono zbiory biblioteczne, przynajmniej z formalno-prawnego punktu widzenia nie zależały od widzimisię urzędującego bibliotekarza. Określały je wyraźnie statuty i regulaminy biblioteczne. Nadrzędnym celem bibliotek naukowych była możliwa kompletność poszczególnych działów, bez upośledzania lub uprzywilejowania jednych względem drugich ${ }^{69}$ lub też kompletność w zakresie wybranych działów ${ }^{70}$. Wobec tego może się wydawać wątpliwe traktowanie realizacji przez bibliotekarzy ustalonych wytycznych gromadzenia w kategoriach osiągnięć. A jednak nie sposób nazywać ich inaczej, mając w pamięci ciągłe problemy finansowe, z którymi borykały się ówczesne biblioteki. Na dodatek nie było wcale rzadkością, zwłaszcza u bibliotekarzy uniwersyteckich, wywodzących się z kręgu profesorskiego, faworyzowanie własnej dyscypliny lub kierowanie się własnymi pryncypiami. F.G. Welcker na przykład odrzucał planowe kompletowanie wszystkich dziedzin, gdyż uważał je za zbyt kosztowne i wymagające wysiłku. Troszczył się bardziej o równomierność w zakresie poszczególnych dyscyplin ${ }^{71}$. Całkowicie odmienny pogląd na ten temat wyznawał jego następca, F.W. Ritschl ${ }^{72}$. Znaczący udział w systematycznym i szybkim pomnożeniu księgozbioru BU w Marburgu, które rozpoczęło się w 1837 r., miał Karl Julius Caesar ${ }^{73}$. Równomiernością i kompletnością starał się kierować również R. von Mohl z Tybingi. Uważał jednak, że nie sprzyja temu współdecydowanie wydziałów w sprawie gromadzenia: „Przy teraźniejszej ekspansji literatury, żaden bibliotekarz i żadne kolegium nie byliby

${ }^{68}$ Zwyczaj ten upadł po 1850 r. Käuffer zostawił też potomności niepochlebną opinię o radzie miejskiej (z 15 lipca 1821): „dzisiejsza biblioteka powinna być biblioteką miejską, a nie widzę, żeby miasto od dłuższego czasu dawało coś więcej niż plac". Zob. M. Reuther, Geschichte des Bibliothekswesens in der Stadt Bautzen, Bautzen 1955, s. 21.

69 Zob. Reglement für die Universitätsbibliothek (zu Bonn). Vom 25 August 1819, „IntelligenzBlatt zum Serapeum" 1845, Nr. 8, s. 60-61; Statut für die Grossherzogliche Hoffbibliothek in Karlsruhe, „Intelligenz-Blatt zum Serapeum” 1846, Nr. 2, s. 9-12.

${ }_{70}$ Revidierte Gesetze für die Hamburgische Stadtbibliothek (Auf Befehl) eines Hochedlen Raths der Freien und Hanse - Stadt Hamburg publiziert am 1.März 1844, „Intelligenz-Blatt zum Serapeum” 1845, Nr. 2, s. 9-14.

71 W. Erman, op. cit., s. 109.

72 Ritschl traktował równomiernie wszystkie działy. Usuwał odczuwalne braki w poszczególnych partiach księgozbioru, unikał zakupu małych, efemerycznych publikacji. Zob. W. Erman, op. cit., s. 175.

${ }^{73}$ C. Boysen, Zwei hessische Bibliothekare, „Centralblatt für Bibliothekswesen” 1886, H. 12, s. 518. Wcześniej kupowano okazyjnie głównie prywatne biblioteki. 
rozsądni, gdyby twierdzili, że znane są im wszystkie dyscypliny jednakowo [...] Jednak dzisiejsze rozdrobnienie budżetu między 20 osób uprawnionych do składania propozycji powoduje dalece gorsze skutki" ${ }^{\prime 74}$. Tradycje zapoczątkowane przez Mohla kontynuował Johannes Baptista Fallati. Wspierał różne wydziały w ich propozycjach uzupełniania zbiorów, bacznie przy tym obserwując, by nie powstały luki w zbio$\mathrm{rach}^{75}$. Planową i przemyślaną politykę gromadzenia prowadzili też bibliotekarze dworscy, jak np. J.G. Geissler (Gotha), F. Wilken (Berlin), J.Ch. Adelung (Drezno) oraz kolejni hamburscy bibliotekarze miejscy, od Ch.D. Ebelinga począwszy. Zasługi Christiana Gottloba Heynego (BU Getynga), J.Ch. Adelunga (BD Drezno) i Ch.D. Ebelinga zwielokrotnia fakt, iż byli oni autorami wytycznych gromadzenia zbiorów ${ }^{76}$, które na długo legły u podstaw funkcjonowania bibliotek.

\section{Przechowywanie zbiorów}

Wiek XIX generalnie przyniósł niemieckim bibliotekarzom przyrost zbiorów, często lawinowy w przypadku, gdy źródłem wpływów była sekularyzacja zakonów, rozwiązanie uniwersytetów czy hojność darczyńców. Sprostanie nowym wyzwaniom nie było wcale łatwe, zważywszy na to, że środków finansowych brakowało nie tylko na budowę nowych gmachów, ale często na bieżące funkcjonowanie biblioteki. Szukano więc rozwiązań pośrednich, tj. remontowano budynki, rozbudowywano stare gmachy, przeprowadzano biblioteki do innych budynków, też starych, aczkolwiek przestronniejszych. Na nowe, funkcjonalne gmachy stać było jedynie większe biblioteki, zlokalizowane w bogatych miastach i krajach, np. w Hamburgu czy Monachium. Udział bibliotekarzy w tej sferze działalności bibliotek nie należał do zbytnio rzucających się w oczy, ale też ich możliwości ograniczały się często do wnioskowania i monitowania u władz zwierzchnich. Bezskutecznie walczył o nowe pomieszczenia dla biblioteki uniwersyteckiej w Bonn F.W. Ritschl. Jego antagonistami w tym sporze byli kurator uniwersytecki W. Beseler i inspektor budowlany Dickehof. W jednym z listów do kuratora dramatycznie wołał: „Zmiana nie będzie

${ }^{74}$ K. Geiger, Robert von Mohl..., s. 182. Nadbibliotekarz dysponował około 1/3 całego funduszu na gromadzenie. Pozostałe $2 / 3$ pozostawały do dyspozycji poszczególnych wydziałów i należących do nich instytutów. Zob. też P.M. Ehrle, op. cit., s. 24.

${ }^{75}$ Nekrolog des Oberbibliothekars Fallati in Tübingen, „Anzeiger der Bibliographie und Bibliothekswissenschaft" 1855, H. 12, s. 370.

${ }^{76}$ Zob. F.A. Ebert, Geschichte und Beschreibung der Königlichen öffentlichen Bibliothek zu Dresden, Leipzig 1822, s. 104 i nast.; Heynes Bericht von 1810, [w:] Vier Dokumente zur Geschichte der Universitätsbibliothek Göttingen, Hrsg. von K. J. Hartmann, Göttingen 1937, s. 14-18; Ch. Petersen, op. cit., s. 110-112. 
możliwa dotąd, aż urzędnicy budowlani nie uznają, że urzędnicy są dla uniwersytetu, a nie uniwersytet dla wygody i sobiepaństwa urzędników"77.

Problemy z rzemieślnikami budowlanymi, choć innego typu, były też zmorą H.J. Jäcka w Bambergu ${ }^{78}$. O wiele więcej szczęścia miał natomiast J.Ch.F. Bähr (BU Heidelberg). Zaledwie w 4 tygodnie po objęciu urzędu nadbibliotekarza (1833) postawił wniosek o dobudowanie trzeciego piętra do biblioteki. Wniosek swój uzasadnił tym, że „dotąd urządzone pierwsze i drugie piętro nie dają już więcej przestrzeni na ustawienie książek, które są za bardzo ścieśnione i jedne na drugich ustawione na kupie, tak że oprócz trudności z wyjmowaniem i ustawianiem książek na wyższych półkach (co jest związane z zagrożeniem życia), jednocześnie jest przez to utrudnione zaprowadzenie w bibliotece trwałego porządku i utrzymanie, podczas gdy wiele książek z braku miejsca musi leżeć w dolnych salach na podłodze"79. Nie wiadomo, które $\mathrm{z}$ argumentów Bähra przeważyły, w każdym razie ministerstwo spraw wewnętrznych zatwierdziło w końcu 1833 r. 1100 guldenów na budowę trzeciego piętra. Rozbudowę rozpoczęto w 1834 r. i trwała od 1852 r. ${ }^{80}$ Szczególną dumą napawał Bähra fakt połączenia pięter ze sobą żelaznymi krętymi schodami, które nazywał chlubą biblioteki, a sam rozbudowany gmach jego zdaniem nie miał porównania po tych przeróbkach $\mathrm{z}$ innymi lokalami bibliotecznymi ${ }^{81}$.

W przebudowie biblioteki uczestniczyli też inni bibliotekarze uniwersyteccy, dworscy i miejscy: J.M. Hartmann (BU Marburg) $)^{82}$, R. von Mohl (BU Tybinga) ${ }^{83}$, J.E. Biester (BD Berlin) ${ }^{84}$, Ludwig Konrad Bethmann (BD Wolenbüttel) ${ }^{85}$, Wilhelm Mantels (BM Lubeka) ${ }^{86}$, Georg Friedrich Gerloff (BM Magdeburg) ${ }^{87}$.

77 W. Erman, op. cit., s. 171. Jedynym sukcesem Ritschla było utworzenie wypożyczalni w osobnym pomieszczeniu (1858). Istotna poprawa warunków pracy bibliotekarzy i użytkowania zbiorów nastąpiła dopiero po 1871 r., za kadencji J. Bernaysa.

78 Jäck zakwestionował kosztorys naprawy dachu biblioteki, przeprowadzonej w 1826 r. po 16 latach przerwy. Niestety, jego interwencja pozostała bez skutku, a malwersacje - bezkarne. Zob. H.J. Jaeck, op. cit., s. XCI.

${ }_{79}$ H. Vogeler, op. cit., s. 72. Bähr prosił w owym piśmie również o odpowiedni piec do ogrzewania pomieszczeń.

${ }^{80}$ Ibidem, s. 72-73.

${ }^{81}$ Ibidem, s. 74. Pomieszczenia biblioteki uniwersyteckiej były wystarczające do końca urzędowania Bähra (1874).

${ }^{82}$ K. Bader, op. cit., s. 95.

83 Powiększył bibliotekę o nowe pomieszczenia. Zob. H. Widmann, Die Zugänglichkeit der Universitätsbibliothek Tübingen (Bis zur Mitte des 19. Jahrhunderts), [w:] Aus der Welt des Bibliothekars, Festschrift für Rudolf Juchhoff zum 65. Geburtstag / hrsg. von K. Ohly und W. Krieg, Köln 1960, s. 224.

${ }^{84}$ Utworzył on odrębne pomieszczenia do prowadzenia manuskryptów. Zob. F. Wilken, op. cit., s. 122.

85 Bibliothekar Dr. Konrad Bethmann, „Neuer Anzeiger für Bibliographie und Bibliothekswissenschaft" Februar 1868, s. 40.

${ }^{86}$ K. Bader, op. cit., s. 158-158.

87 Ibidem, s. 73. 
Porównywalne, a nawet przewyższające sukces Bähra, są osiągnięcia C.W. Göttlinga (BU Jena) na polu przechowywania zbiorów. Składają się na nie: oczyszczenie przedniej strony biblioteki (1844 r.), wyłożenie strony południowej płytkami kamiennymi (1845 r.), reperacja pokojów bibliotecznych (1852 r.). Finałem tych systematycznych prac remontowych była przeprowadzka do nowego gmachu (1858 r. $)^{88}$. Przeprowadzki do nowych gmachów odnotowali na swoim koncie również: K.G. Gersdorf (BU Lipsk) w 1846 r. ${ }^{89}$, Christoph Ludolf Ehrenfried Krehl (BU Lipsk) w 1891 r. $^{90}$, Otto Preuss ${ }^{91}$, Georg Heinrich Ludwig Nicolovius i Schulz (BD Królewiec) ${ }^{92}$, Heinrich Konrad Föringer (BD Monachium) $)^{93}$. Przeprowadzkami bibliotek do starych, aczkolwiek przestronniejszych budynków kierowali m.in. Georg Gottlieb Güldenapfel (BU Jena) ${ }^{94}$, Johann Ernst Christian Schmidt (BU Giessen) ${ }^{95}$, Karl Wilhelm Dassdorf ${ }^{96}$, Johann Friedrich Gustav Gentzen (BD Neustrelitz) ${ }^{97}$, Karl Wilhelm Ferdinand Büchner (BD Schwerin) ${ }^{98}$, Joseph Gerhard Laurent (BM Akwizgran $)^{99}$. Przeprowadzka - czy to do nowego, czy starego gmachu - tak wówczas, jak i obecnie pozostawała skomplikowanym organizacyjnym oraz technicznym przedsięwzięciem. Przeniesienie całej biblioteki wymagało nie lada talentu i można powiedzieć, że było najlepszym sprawdzianem kwalifikacji bibliotekarskich ${ }^{100}$.

${ }^{88}$ Geschichte der Universitätsbibliothek Jena..., s. 458 i nast.

${ }^{89}$ G. Loh, op. cit., s. 51. Przeprowadzka spowodowała przyhamowanie innych prac.

${ }^{90}$ E. Zarnecke, Ludolf Krehl, „Zentralblatt für Bibliothekswesen” 1901, H. 12, s. 617. Krehl kierował przeprowadzką w wieku 66 lat.

${ }_{91}$ K. Bader, op. cit., s. 198.

92 E. Kuhnert, Geschichte der Staats-und Universitäts-Bibliothek zu Königsberg. Von ihrer Begründung bis zum Jahre 1810, Leipzig 1926, s. 38. Nicolovius przygotował bibliotekę do przeniesienia, był też autorem memoriału do rządu (28 czerwca 1808), który wpłynął na decyzję o przeprowadzce. Jej wykonawcą był natomiast Schulz.

${ }^{93}$ K. Bader, op. cit., s. 62. Był on duszą przeprowadzki. Totalnej krytyce funkcjonalność tego budynku poddał J. Petzholdt, zachwycony zarazem jego wyglądem zewnętrznym. Zob. J. Petzholdt, Ein Ausflug nach Augsburg und München, „Neuer Anzeiger für Bibliographie und Bibliothekswissenschaft” 1858, Juli, s. 203.

94 Przetransportował on bibliotekę zamkową do pomieszczeń biblioteki uniwersyteckiej (1818-19). Zob. Geschichte der Universitätsbibliothek..., s. 429-430.

${ }_{95} \mathrm{~J}$. Schmidt uchronił bibliotekę przed pożarem, przeprowadzając ją do koszar. Zob. K. Bader, op. cit., s. 230.

${ }^{96}$ K.W. Dassdorf wykazał się w czasie przeprowadzki z Zwingeru do pałacu japońskiego (1778 r.). Zob. K. Bader, op. cit., s. 40.

${ }_{97}$ F. Latendorf, Die Grossherzogliche Bibliothek zu Neustrelitz und ihre litterarischen Seltenheiten, „Serapeum” 1858, Nr. 20, s. 306.

98 K. Bader, op. cit., s. 29.

99 Ibidem, s. 114.

${ }^{100}$ Na przykład Joseph Förstemann (BU Halle) sprawdził się w czasie przeprowadzki biblioteki przez prawidłowe obliczenie powierzchni biblioteki. Zob. K. Bader, op. cit., s. 63. 
Innowacje bibliotekarzy w zakresie przechowywania zbiorów miały też drobniejszy wymiar, gdy chcieć je zestawić np. z przeprowadzką biblioteki. Na owe czasy jednak oznaczały swoistą rewolucję. W tych kategoriach należy widzieć zastąpienie repozytoriów stołami przez J. E. Biestera ${ }^{101} \mathrm{czy}$ wprowadzenie do biblioteki zamiast pulpitów stołów i krzeseł przez G.H.L. Nicoloviusa (BD Królewiec) ${ }^{102}$. Rewolucyjną zmianą mogło być również zaprowadzenie ogrzewania w pokojach, jak tego dowodzi przykład Wolfenbüttel. Dokonano tego dopiero w 1833 r. na wniosek K.P.Ch. Schönemanna ${ }^{103}$.

\section{Ustawienie zbiorów}

Kluczem do szybkiego odszukania żądanej przez użytkownika książki było oprócz włączenia opisu do katalogu - bezwzględnie jej odpowiednie ustawienie. Świadomość tego narastała w umysłach dziewiętnastowiecznych bibliotekarzy - trzeba przyznać - bardzo powoli. Nierzadko jeszcze w pierwszym ćwierćwieczu tego stulecia ustawiano zbiory według formatów, tak jak to miało miejsce w bibliotece miejskiej w Budziszynie ${ }^{104}$. W bibliotekach naukowych dominował już jednak rzeczowy układ zbiorów. Spory między bibliotekarzami dotyczyły raczej samej systematyki zbiorów, aniżeli tego, czy ustawić księgozbiór rzeczowo. Impulsem do szybkiego rozstrzygania wątpliwości często była konieczność zarówno scalenia stojących dotąd oddzielnie księgozbiorów, jak i włączenia księgozbiorów obcego pochodzenia, niekiedy zaś zwiększenia efektywności użytkowania zbiorów. Przed zadaniem pierwszego typu stanęli m.in. J.E. Biester (BD Berlin) i F.A. Ebert (BD Drezno). Pierwszy za zgodą ministra Johanna Christopha von Wöllnera rozpoczął w 1790 r. scalanie ustawionych dotąd oddzielnie księgozbiorów, liczących łącznie około 150000 tomów ${ }^{105}$. Plan Biestera dotyczył ustawienia działów: filologia, literatura starożytna, historia, dzieła encyklopedyczne. Jego autor wzorował się na układzie opracowanym przez saksońskiego bibliotekarza Johanna Michaela Franckego, czego wymownym świadectwem było

101 F. Wilken, op. cit., s. 122.

102 E. Kuhnert, op. cit., s. 38.

103 Potwierdza to własnymi słowami w nekrologu Schönemanna L. Schweiger: „Był to wówczas rzeczywiście widok godny politowania, posiwiałego urzędnika w zimie z członkami drżącymi od zimna, przechylającego się 2 godziny przez rotundę biblioteki. O korzystaniu z rękopisów i książek w ostrych zimowych czasach nie było mowy”. Zob. L. Schweiger, Zur Erinnerung an C. W.F. Stephan, „Serapeum” 1862, Nr. 10, s. 145-156; Nr. 11, s. 121.

104 M. Reuther, op. cit., s. 20.

105 Były to: Stara Biblioteka Królewska, Biblioteka Spannheima, Biblioteka pułkownika Quintusa Icilusa, Nowa Biblioteka Królewska. Zob. Deutsche Staatsbibliothek..., s. 141; F. Wilken, op. cit., s. 116. 
przyjęcie w dziale „Historia kraju” topograficznego punktu widzenia ${ }^{106}$. W sprawozdaniu z 22 lutego 1796 r. Biester wspominał, że zajmie się tylko przednią częścią biblioteki, a tylną przejmie bibliotekarz Jean Henry ${ }^{107}$. Zdaje się też potwierdzać to, że w latach 1818/19 F. Wilken podjął się ustawienia całej biblioteki na nowo. Dokonał tego przy pomocy studentów w ciągu 6 miesięcy. W istocie rzeczy zmienił on ustawienie Biestera nieznacznie, odnawiając jedynie podział na grupy i podgrupy oraz dostosowując go do ówczesnego stanu wiedzy. Zachował przy tym najważniejszą cechę starego układu, tj. topograficzne kryterium wewnątrz regionalnej literatury fachowej ${ }^{108}$. Tłumaczył to Wilken tym, że „ustawienie to (choć) niewygodne, przez to, że liczne działy, które ze swej natury powinny być połączone, stoją oddzielnie, ale zważywszy na właściwości pomieszczeń, jest mniej niewygodne niż się wydaje"109. Wilken kierował się przy tej pracy naczelną zasadą, by książki można było szybko odstawiać na półkę - temu służyło równoległe sporządzanie wykazów topograficznych ${ }^{110}$.

Przed podobnym zadaniem jak Biester został postawiony w Wolfenbüttel F.A. Ebert. Polegało ono na połączeniu ze sobą dotychczas oddzielnie ustawionych 5 księgozbiorów ${ }^{111}$. Również jemu udało się zrealizować cel tylko częściowo. Zdążył ustawić systematycznie - według zaprojektowanego przez siebie systemu - nową bibliotekę. Połączenie z nią starej biblioteki uniemożliwiła mu obecność w tym ostatnim księgozbiorze wielu klocków introligatorskich. Rozpoczął wprawdzie ich rozwiązywanie, ale nie ukończył tego zadania, opuściwszy po 2 latach pobytu Wolfenbüttel ${ }^{112}$. Częste zmiany na stanowisku bibliotekarza w następnych latach sprawiły, że kontynuowania dzieła Eberta podjął się dopiero K.P.Ch. Schönemann (1831 r.). Ustawienie klasyków greckich i łacińskich oraz lingwistyki i historii literatury przyszło mu bez trudu. Utknął jednak na tym samym, co Ebert, czyli na klockach introligatorskich. Dokończył ich rozwiązywanie, ale nie zdołał włączyć ich do księgozbioru. Uniemożliwił mu to brak pieniędzy na nowe oprawy, ponadto brak

${ }^{106}$ Polegał on na umieszczeniu w obrębie kraju wszystkich dzieł jego dotyczących, włącznie z podróżami, statystyką, Kościołem itd. Zob. Deutsche Staatsbibliothek..., s. 142; F. Wilken, op. cit., s. 116-118.

107 F. Wilken, op. cit., s. 116-118.

108 Deutsche Staatsbibliothek..., s. 144.

109 Wilken, op. cit., s. 207.

110 F. Wilken nazywał je inwentarzami. Numer działu lub poddziału był nanoszony na wewnętrzną stronę tylnej okładki książki. Zob. Deutsche Staatsbibliothek..., s. 144.

111 F. Nestler, op. cit., s. 99. Do 1823 r. Bibliotekę Książęcą w Wolfenbüttel współtworzyły: Stara Biblioteka Augustyńska, Nowa Biblioteka, Biblioteka Księżnej Filipiny Charlotty, Zbiór biblii księżnej Elżbiety Zofii Marii, Zbiór rękopisów.

112 Ebert chciał scalić odrębne księgozbiory, dział po dziale w jeden zbiór, zaczynając od najczęściej użytkowanych dziedzin, a potem skatalogować całość. Zob. F. Nestler, op. cit., s. 100. 
jakiejkolwiek pomocy oraz natłok bieżących obowiązków ${ }^{113}$. Do szczęśliwego końca ustawienie biblioteki na nowo doprowadził dopiero w 1865 r. L.K. Bethmann ${ }^{114}$.

Niewyobrażalnie trudniejsze przedsięwzięcie mieli przed sobą na początku XIX wieku bibliotekarze monachijskiej biblioteki dworskiej. Po przejęciu książek ze zlikwidowanych klasztorów w zbiorach biblioteki zgromadzono ponad 300000 dzieł, które należało ustawić na półkach i skatalogować. Nic dziwnego zatem, że nie podołali temu nawet tacy wielcy bibliotekarze, jak Johann Ch. von Aretin i Julius W. Hamberger ${ }^{115}$. W tej sytuacji ministerstwo zaleciło bibliotekarzowi Johannowi Schererowi przedstawienie planu ostatecznego uporządkowania biblioteki (1813 r.). Autorem projektu i jego wykonawcą był Martin Schrettinger. W ciągu 4 lat (18141818) przy pomocy diurnistów (sił pomocniczych) ustawił, oznakował i skatalogował alfabetycznie całą bibliotekę według nakreślonego przez siebie planu ${ }^{116}$. Po latach (1828 r.) wspominał o tym nie bez pewnej satysfakcji: „W naszej królewskiej bibliotece dworskiej, jak wiadomo, od jej jednorazowego ogromnego wzbogacenia próbowane były dwojakie plany urządzenia, jeden po drugim, a każdy odrzucano po upływie 6 lat jako niewykonalny i niecelowy, co każdorazowo przepowiadałem, ale jako podwładny nie znajdowałem żadnego posłuchu u ówczesnych przełożonych. Także mój podręcznik, w którym już przed 20 laty moją metodę urządzenia biblioteki [...] przedstawiłem publiczności, nie spotkała się z godną uwagą, aż wreszcie po 12 latach bezcelowych i bezowocnych prac Dir. Joseph Scherer po raz trzeci rozpoczynając z tym (porządkowanie) od nowa, nakazał całą bibliotekę według mojego planu ustawić, oznakować i skatalogować alfabetycznie, co w ciągu 4 lat (od 1814 do 1818) z o wiele za małą liczbą współpracowników zostało dokonane"117.

Chęć szybkiego dostarczenia użytkownikowi poszukiwanej książki przyświecała J.B. Fallatiemu przy tworzeniu i wprowadzaniu w życie układu książek. Wykorzystał

113 L. Schweiger, Zur Erinnerung on..., nr 11, s. 120-121.

114 Bethmann opierał się zasadniczo na wytycznych Eberta. Zob. F. Nestler, op. cit., s. 103.

115 Aretin nie zdołał przekonać komisji Akademii Nauk do swojego planu. Sprowadzony z Gothy Hamberger rozpoczął systematyczne ustawienie zbiorów według schematu przyjętego w getyńskiej bibliotece uniwersyteckiej; zachorowawszy jednak, nie doprowadził swego dzieła do końca. Zob. Z. Żmigrodzki, Martina Schrettingera koncepcje rzeczowej charakterystyki dokumentów, [w:] Opracowanie rzeczowe zbiorów w dużych bibliotekach uniwersalnych, Warszawa 1989, s. 53.

116 Zob. ibidem, s. 54; K. Haller, Über die Beschreibung der Bücher: zur Geschichte der Münchener Katalogisierungs-Ordnung, „Bibliotheksforum Bayern” 1979, H. 2, s. 99-108.

117 K. Haller, op. cit., s. 100. Zob. też M. Schrettinger: Versuch eines vollständigen Lehrbuches der Bibliothek-Wissenschaft, München 1808, H. 1, s. 46-70. Schrettinger podzielił zbiory na 12 działów głównych z poddziałami tylko pierwszego stopnia, a w ich obrębie według formatu (numeru bieżącego). 
ku temu dogodny moment, tj. przeprowadzkę biblioteki do nowego gmachu (lato 1850 r.). Z obu zadaniami uporał się bardzo szybko, w ciągu 3 miesięcy ${ }^{118}$.

Autorami nowych systemów ustawienia książek byli też: H.B. Wenck (BD Darmstadt) ${ }^{119}$, Wilhelm Müller (BD Dessau) ${ }^{120}$, E.R.W. Naumann (BM Lipsk) $)^{121}$, J.E. Kaüffer (BM Budziszyn) ${ }^{122}$. Maurus Aloys Harter (BU Monachium) zamierzał ustawić księgozbiór monachijskiej biblioteki uniwersyteckiej na wzór getyński. W tym celu udał się nawet do Getyngi. Niestety, nie mógł zrealizować swojego pomysłu z powodu braku miejsca ${ }^{123}$.

\section{Zbiory specjalne}

Lwią część dziewiętnastowiecznych bibliotek, zwłaszcza naukowych, stanowiły zbiory specjalne, a wśród nich rękopisy i inkunabuły. Był to spadek przeważnie po likwidowanych bibliotekach klasztornych - bezcenny, aczkolwiek nieco kłopotliwy. Uporządkowanie rękopisów, inkunabułów czy zbiorów kartograficznych wymagało nie tylko nie lada wiedzy, ale też niezmiernego trudu. Przykładem niech będzie Adolf Friedrich Stenzler (BU Wrocław), który uporządkował w ciągu 20 lat 3000 inkunabułów i ustawił je w dwóch wolnych pomieszczeniach ${ }^{124}$. Przez 16 lat (18331849) porządkował mapy, atlasy i globusy w berlińskiej bibliotece królewskiej jej kustosz Johann Marius Friedrich Schmidt. Krótko przed śmiercią (1852 r.) ukończył jeszcze wykaz zbiorów kartograficznych ${ }^{125}$. Wybitne zasługi przy porządkowaniu rękopisów położyli dwaj inni bibliotekarze dworscy Friedrich Jacobs (BD Gotha) i Johann Andreas Schmeller (BD Monachium) ${ }^{126}$. F. Jacobs wespół z Juliusem Wilhelmem Hambergerem ponumerował i ustawił wszystkie rękopisy ${ }^{127}$. Zasługą J.A. Schmellera było natomiast ułożenie rękopisów według pochodzenia w porządku alfabetycznym ${ }^{128}$. Nowinki w przechowywaniu zbiorów przyjmowały się nie bez

118 Zob. K. Geiger, Johannes Fallati als Tübinger Oberbibliothekar, „Zentralblatt für Bibliothekswesen” 1908, H. 8-8, s. 407-408. Ówczesna biblioteka uniwersytecka liczyła około 100000 tomów.

119 H. Berndt, op. cit., s. 37-38.

120 K. Bader, op. cit., s. 178.

121 H.-Ch. Mannschatz, op. cit., s. 159.

122 M. Reuther, op. cit., s. 21.

123 L. Buzás, Geschichte der Universitätsbibliothek..., s. 104-105; G. Leyh, op. cit., s. 290.

124 G. Leyh, op. cit., s. 284.

125 Niestety, jego dzieło zostało częściowo zaprzepaszczone, nad czym ubolewał Friedländer. Zob. Deutsche Staatsbibliothek..., s. 409-410.

126 Jest tu mowa wyłącznie o ustawieniu zbiorów specjalnych.

127 F. Jacobs, F.A. Ukert, Beiträge zur ältern Litteratur oder Merkwürdigkeiten der Herzogl. öffentlichen Bibliothek zu Gotha, Bd. 1, Leipzig 1835, s. 31-32.

128 P. Ruf, Schmeller als Bibliothekar, [w:] Festgabe der Bayerischen Staatsbibliothek, Emil Gratzl zum 75. Geburtstag, München 1953, s. 23-53. 
oporów. Stosowną egzemplifikacją tego twierdzenia jest nadawanie książkom znaków własnościowych. Indywidualną sygnaturę książkową wprowadził w Getyndze wzorem Drezna dopiero Ch.G. Heyne. W Tybindze ojcem tej innowacji był Georg Leonhard von Dresch ${ }^{129}$. Niewątpliwie autorem najbardziej trwałego w tym względzie urządzenia był G.G. Güldenapfel (BU Jena). W latach 1818-1819 ustawił on księgozbiór w 32 działach głównych i licznych poddziałach. Do oznaczania działów wymyślił specjalną sygnaturę, składającą się ze skróconej nazwy działu głównego, rzymskiej cyfry dla oznaczenia poddziału oraz cyfry arabskiej dla oznaczenia pojedynczej książki. Tak system ustawienia, jak też sygnatura przetrwały aż do 1949 r. ${ }^{130}$

Wąskim, za to bardzo ważnym z uwagi na pieniądze odcinkiem pracy dziewiętnastowiecznego bibliotekarza była oprawa książek. Na tym tle dochodziło zazwyczaj do konfliktów między bibliotekarzami a introligatorami. W spór taki wszedł m.in. F.A. Ebert. Troszczył się on nie tylko o jakość, ale i o cenę opraw. Dlatego też w $1831 \mathrm{r}$. rozpisał konkurs na prace introligatorskie dla biblioteki. W rezultacie wybrał spośród 12 kandydatów jednego, który oferował najniższe ceny ${ }^{131}$.

\section{Zakończenie}

Czytając opracowania o dziewiętnastowiecznych bibliotekach niemieckich, studiując teksty źródłowe o nich, chciałoby się powiedzieć, że nielekko było być w tamtych czasach bibliotekarzem. Ciągłe problemy, walka o pieniądze na zakup książek, niemożność poprawy warunków pracy, brak możliwości zatrudnienia dodatkowych pracowników, batalie o darowizny, regularny dopływ egzemplarza obowiązkowego, w dodatku wpisane w czasy, w których wcale nierzadko Muzy musiały ustąpić przed dźwiękiem wystrzałów armat. Jednocześnie chciałoby się rzec - nihil novi sub sole. Wiele $\mathrm{z}$ tych problemów jest powszechnych wśród współczesnych bibliotek przełomu XX i XXI wieku. Przewaga darów nad zakupami. Brak dostatecznych środków na uzupełnienie luk w księgozbiorze. Nieregularne dostarczanie egzemplarza obowiązkowego i boje z wydawcami w tej sprawie. Niechęć bibliotek do wymiany i wypożyczeń międzybibliotecznych. Redukowanie budżetu bibliotek przez ich organizatorów (szkoły wyższe, państwo, samorząd). Brak wytycznych gromadzenia. Prywata w zakresie gromadzenia zbiorów. Wieloletnie oczekiwania

129 G. Leyh, op. cit., s. 291.

130 R.-M. Kiel, Goethe und das Bibliothekswesen in Jena und Weimar, „Bibliothek und Wissenschaft” 1981, s. 49. Przykładowa sygnatura to: Zool. III, F4. Zob. też K. Marwinski, 425 Jahre Universitätsbibliothek Jena: 1558-1983, Jena 1983, s. 70 i nast.

131 F. Nestler, op. cit., s. 111. 
na przeprowadzkę biblioteki do większych lokali. Niewłaściwe ustawienie zbiorów. Jednakże bibliotekarze niemieccy z bibliotek uniwersyteckich, dworskich i miejskich nie poddawali się, nie zakładali rąk, ale stawiali czoła piętrzącym się problemom, dowodząc tężyzny ducha i ciała. Warto nawet dziś brać z nich przykład.

\section{Bibliografia}

Bader K., Lexikon deutscher Bibliothekare in Haupt- und Nebenamt bei Fürsten, Staaten und Städten, Leipzig 1925.

Berndt H., Vom Berufsbild der Darmstädter Bibliothekare, [w:] Durch der Jahrhunderte Strom. Beiträge zur Geschichte der Hessischen Landes-und Hochschulbibliothek Darmstadt, Hrsg. E. Zimmermann, Frankfurt a. M 1967, s. 30-58.

Bibliothekar Dr. Konrad Bethmann, „Neuer Anzeiger für Bibliographie und Bibliothekswissenschaft" 1868 Februar, s. 37-41.

Boysen C., Carl Julius Caesar, „Zentralblatt für Bibliothekswesen” 1886, H. 12, s. 514-524.

Buzás L., Deutsche Bibliotheksgeschichte der neuesten Zeit (1800-1945), Wiesbaden 1978.

Buzás L., Geschichte der Universitätsbibliothek München, Wiesbaden 1972.

Crusius G., Gründung und Frühgeschichte der Herzoglichen öffentlichen Bibliothek in Oldenburg (1792-1847), Oldenburg 1981.

Deutsche Staatsbibliothek 1661-1961, H. Kunze i in., Leipzig 1961.

Ebert F. A., Geschichte und Beschreibung der Königlichen öffentlichen Bibliothek zu Dresden, Leipzig 1822.

Ehrle P.M., Bibliothekspolitik im Vormärz. Robert von Mohl und die Universitätsbibliothek Tübingen, [w:] Bibliotheken im gesellschaftlichen und kulturellen Wandel des 19. Jahrhundert, Referate des 1. Jahrestreffens der Wolfenbütteler Arbeitskreises für Bibliotheksgeschichte vom 24. bis 26. April 1980 in der Herzog-August-Bibliothek / hrsg. von G. Liebers und P. Vodosek, Hamburg 1982, s. 19-33.

Erman W., Geschichte der Bonner Universitätsbibliothek (1818-1901), Halle 1919.

Fabian B., Die Göttinger Universitätsbibliothek im achtzehnten Jahrhundert, „Göttinger Jahrbuch" 1980, s. 109-123.

Geiger K., Johannes Fallati als Tübinger Oberbibliothekar, „Zentralblatt für Bibliothekswesen” 1908, s. 389-415.

Geiger K., Robert Mohl als Vorstand der Tübinger Universitätsbibliothek (1836-1844), „Zentralblatt für Bibliothekswesen" 1900, H. 17, s. 161-191.

Geschichte der Göttinger Universitätsbibliothek, Hrsg. von K. J. Hartmann, H. Fuchsel, Göttingen 1937.

Gębołyś Z., Uczeni, poeci i inni bibliotekarze miejscy na ziemiach niemieckich w latach 1789-1871, [w:] Kultura książi i informacji. Księga jubileuszowa dedykowana Profesor Elżbiecie Gondek, red. A. Pulikowski, Katowice 2017, s. 211-232.

Haller K., Über die Beschreibung der Bücher: zur Geschichte der Münchener KatalogisierungsOrdnung, „Bibliotheksforum Bayern” 1979, H. 2, s. 99-108. 
Handbuch der Bibliothekswissenschaft, Begründet von F. Milkau 2 verm. und verbes. Aufl. Hrsg. von G. Leyh, Bd. 1-3, Wiesbaden 1952-1961.

Hessel A., Heyne als Bibliothekar, „Zentralblatt für Bibliothekswesen” 1928, H. 9-10, s. $255-$ 270.

Heynes Bericht von 1810, [w:] Vier Dokumente zur Geschichte der Universitätsbibliothek Göttingen, Hrsg. von K. J. Hartmann, Göttingen 1937, s. 14-18.

Irmischer J.C., Diplomatische Beschreibung der Manuscripte welche sich in der Königl. Universitätsbibliothek Erlangen befinden, Erlangen 1829.

Jacobs F., Ukert F.A., Beiträge zur ältern Litteratur oder Merkwürdigkeiten der Herzogl. öffentlichen Bibliothek zu Gotha, Bd. 1-3, Leipzig 1835-1843.

Jaeck H.-J., Völlstandige Beschreibung der öffentlichen Bibliothek zu Bamberg, Nürnberg 1831.

Keunecke H.-O., Die Universitätsbibliothek Erlangen als Pflichtbibliothek vor 1840, „Bibliotheksforum Bayern” 1986, H. 2, s. 155-174.

Kiel R.-M., Goethe und das Bibliothekswesen in Jena und Weimar, „Bibliothek und Wissenschaft" 1981, Bd. 15, s. 11-82.

Kohler M., „Ueber öffentliche Anstalten zur Vebesserung der Academischen Sitten”. Studentische und bürgerliche Leseeinrichtungen in der Universität Helmstedt im letzten Drittel des 18. und im frühen 19. Jahrhundert, „Gutenberg-Jahrbuch” 1989, s. 330-363.

Kuhnert E., Geschichte der Staats- Von ihrer Begründung bis zum Jahre 1810, Leipzig 1926.

Landesbibliothek Kassel 1580-1930, Hrsg. von W. Hopf, t. 1-2, Marburg 1930.

Latendorf F., Die Grossherzogliche Bibliothek zu Neustrelitz und ihre litterarischen Seltenheiten. „Serapeum” 1858, Nr. 20, s. 305-317.

Lexikon des gesamten Buchwesens, Hrsg. von K. Löffler und J. Kirchner, Bd. 1-3, Leipzig 1935-1937.

Leyh G., Die deutschen Bibliotheken von der Aufklärung bis zur Gegenwart, Wiesbaden 1956.

Loh G., Ernst Gotthelf Gersdorfs Tätigkeit als Oberbibliothekar an der Universitätsbibliothek Leipzig (1833-1874), [w:] Studien zum Buch-und Bibliothekswesen, Bd. 5, Leipzig 1987, s. $44-64$.

Mannschatz H.-Ch., Zur Erinnerung an Robert Naumann (1809-1880), „Bibliothekar” 1990, H. 3, s. $157-160$.

Marwinski K., 425 Jahre Universitätsbibliothek Jena: 1558-1983, Jena 1983.

Mehl E., Hannemann K., Deutsche Bibliotheksgeschichte, Berlin 1956.

Mühlner M., Begeisterung war die Signatur meiner Tätigkeit: die Reform der Königlichen Öffentlichen Bibliothek in Dresden unter Ernst Wilhelm Förstemann, [w:] Studien zum Buch- und Bibliothekswesen, Bd. 5, Leipzig 1987, s. 81-88.

Nekrolog des Oberbibliothekars Fallati in Tübingen, „Anzeiger der Bibliographie und Bibliothekswissenschaft" 1855, H. 12, s. 363-372.

Nestler F., Friedrich Adolf Ebert und seine Stellung im nationalen Erbe der Bibliothekswissenschaft, Leipzig 1969.

Petersen Ch., Geschichte der Hamburgischen Stadtbibliothek, Hamburg 1838.

Petzholdt J., Ein Ausflug nach Augsburg und München, „Neuer Anzeiger für Bibliographie und Bibliothekswissenschaft" 1858 Juli, s. 201-208.

Reglement für die Universitätsbibliothek (zu Bonn), „Intelligenz-Blatt zum Serapeum” 1845, Nr. 8 s. 57-61; Nr. 9, s. 65-69; Nr. 10, s. 73-77; Nr. 11, s. 81-85. 
Rettung der Wittenberger Universitätsbibliothek im Jahre 1813 durch ihren ersten Custos G.W. Gerlach, „Intelligenz-Blatt zum Serapeum” 1862, Nr. 14, s. 104-108.

Reuther M., Geschichte des Bibliothekswesens in der Stadt Bautzen, Bautzen 1955.

Revidierte Gesetze für die Hamburgische Stadtbibliothek, „Intelligenz-Blatt zum Serapeum” 1845, Nr. 1, s. 1-4; Nr. 2, s. 9-14.

Ruf P., Schmeller als Bibliothekar, [w:] Festgabe der Bayerischen Staatsbibliothek, Emil Gratzl zum 75. Geburtstag, München 1953, s. 9-95.

Schmitz W., Deutsche Bibliotheksgeschichte, Frankfurt a. Main 2007.

Schrettinger M., Versuch eines vollständigen Lehrbuches der Bibliothek-Wissenschaft, Bd. 1-2, München 18081829.

Schweiger L., Zur Erinnerung an C.W.F. Stephan, „Serapeum” 1862, Nr. 10, s. 145-156; Nr. 11, s. 161-168.

Schweiger L., Zur Erinnerung an Dr. Carl Philipp Christian Schönemann, Herzogl. Bibliothekar, und dessen Sohn, Dr. Anton Wilhelm Otto Schönemann, „Serapeum” 1856, Nr. 8, s. $113-128$.

Statut für die Grossherzogliche Hofbibliothek in Karlsruhe, „Intelligenz-Blatt zum Serapeum” 1846, Nr. 1, s. 1-5; Nr. 2, s. 9-12.

Verordnung für die Bibliothek der Grossherzoglichen Ludewigs-Universität zu Giessen, „Intelligenz-Blatt zum Serapeum” 1844, nr 21, s. 161-164; Nr. 22, s. 169-172; Nr. 23, s. 177-180; Nr. 24, s. 185-188.

Vogeler H., Johann Christian Felix Bähr als Oberbibliothekar der Universitätsbibliothek Heidelberg (1832-1872), „Bibliothek und Wissenschaft” 1970, Bd. 7, s. 40-137.

Vorstius J., Joost S., Grundzüge der Bibliotheksgeschichte, 8 Aufl, Wiesbaden 1980.

Weimann K. H., Bibliotheksgeschichte, München 1975.

Widmann H., Die Zugänglichkeit der Universitätsbibliothek Tübingen (Bis zur Mitte des 19. Jahrhunderts), [w:] Aus der Welt des Bibliothekars, Festschrift für Rudolf Juchhoff zum 65. Geburtstag / hrsg. von K. Ohly und W. Krieg, Köln 1960, s. 215-229.

Wilken F., Geschichte der Königlichen Bibliothek zu Berlin, Berlin 1828.

Zarncke E., Ludolf Krehl, „Zentralblatt für Bibliothekswesen” 1901, H. 12, s. 616-618.

Zedler G., Geschichte der Universitätsbibliothek zu Marburg 1527-1887, Marburg 1896.

Żmigrodzki Z., Martina Schrettingera koncepcja rzeczowej charakterystyki dokumentów, [w:] Opracowanie rzeczowe zbiorów w dużych bibliotekach uniwersalnych. Materiały z konferencji 22-24 maja 1986 roku, Jarocin-Warszawa 1989, s. 51-62. 